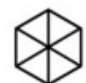 \\ LEUPHANA \\ UNIVERSITÄT LÜNEBURG
}

\section{Offers in English}

\author{
Barron, Anne
}

Published in:

Doing Pragmatics Interculturally

DOI:

10.1515/9783110546095-018

Publication date:

2017

\section{Document Version}

Publisher's PDF, also known as Version of record

Link to publication

Citation for pulished version (APA):

Barron, A. (2017). Offers in English. In R. Giora, \& M. Haugh (Eds.), Doing Pragmatics Interculturally : Cognitive, Philosophical, and Sociopragmatic Perspectives (pp. 335-352). (Trends in linguistics. Studies and monographs; Vol. 312). Walter de Gruyter GmbH. https://doi.org/10.1515/9783110546095-018

\section{General rights}

Copyright and moral rights for the publications made accessible in the public portal are retained by the authors and/or other copyright owners and it is a condition of accessing publications that users recognise and abide by the legal requirements associated with these rights.

- Users may download and print one copy of any publication from the public portal for the purpose of private study or research.

- You may not further distribute the material or use it for any profit-making activity or commercial gain

- You may freely distribute the URL identifying the publication in the public portal ?

If you believe that this document breaches copyright please contact us providing details, and we will remove access to the work immediately and investigate your claim. 


\section{Anne Barron}

\section{Offers in English}

\section{Introduction}

Offers in English have been analysed from various perspectives and using a range of data sources. Studies using corpora as a database include Aijmer (1996), Barron (2011, 2017a), Leech (2014) and Schneider (2003). However, with few exceptions, these studies, some of which focus on a range of speech acts above and beyond offers, do not provide systematic information on the distribution of offer types, strategies or modification in the corpora analysed. In addition, there are no studies on offers using corpus data or other which systematically look at offer types and/ or at realisations of offer strategies and modification by offer type.

The present article, an analysis of offers in private face-to-face conversations in British English, is designed to meet these research gaps. It takes naturally-occurring data from the private face-to-face conversations of the British component of the International Corpus of English (ICE-GB) as its database and systematically investigates how offers are realised in these private conversations, what types of offers (e.g. hospitable offers, offers of assistance) occur and whether correlations exist between offer type and offer strategy, where strategies are understood as various options available to realise an offer (e.g. question desire strategy realised via conventionalised patterns such as Do you want NP?). Furthermore, the relationship between offer type and any pos-politeness and neg-politeness modification strategies employed is investigated. Specifically, the paper addresses the following research questions:

a) What offer types are found in private face-to-face conversation in ICE-GB?

b) Are there any correlations between offer type and offer strategy in private face-to-face conversation in ICE-GB?

c) Are there any correlations between offer type and offer modification (pospoliteness strategies, neg-politeness strategies) in private face-to-face conversation in ICE-GB?

The research adds to the limited scholarship on offers in English. In addition, by addressing the use of the speech act of offers in corpus data, the study also adds to speech act research in corpus pragmatics, an area of research which is still very much in its infancy.

The paper opens with a brief description of the speech act of offers (section 2.1) and an overview of research on offers (section 2.2). Attention then turns to issues of data and method (section 3), including a discussion of offer retrieval 
procedures (section 3.1) and the data source (section 3.2). The empirical analysis of offers in ICE-GB follows (section 4), and the paper concludes with a discussion and suggestions for further research.

\section{Characterising offers}

We begin with a characterisation of offers in section 2.1, and turn then to a brief overview of research on offers to date in section 2.2.

\subsection{The blurred nature of offers}

Offers represent commitments by a speaker (S) to carry out a future course of action (A). They have, thus, been categorised as commissives (Searle 1976: 11; Edmondson and House 1981: 49). At the same time, they involve attempts by $\mathrm{S}$ to get $\mathrm{H}$ to declare him/herself able and willing to engage in the proposed action A (Searle's directives) and so, given this dual nature, have been proposed to belong to the group of commissive directives, a hybrid category proposed by Hancher (1979) to deal with such speech acts which combine directive with commissive illocutionary force equally. Other researchers, however, have rejected the idea that the members of the commissive-directives category share commissive or directive illocutionary force to the same degree. Rather, a continuum of speech acts between the two poles of prototypically commissive and prototypically directive has been proposed by Pérez Hernández (2001: 78), with offers seen as closer to the commissive end of the continuum. Apart from being commissive and directive in nature, offers also involve a conditional component since the execution of an offer is always conditional on the reaction of $\mathrm{H}$ in which he/she indicates in some way whether he/she wishes S to carry out the deed in question A or not (Wunderlich 1977: 43).

These three components of offers, the conditional, the commissive and the directive nature of offers, are reflected in the types of overriding strategies through which offers are conventionally realised, namely, preference, execution and directive strategies (Schneider 2003: 183-185 on hospitable offers). Preference strategies, such as Would you like some scotch?, point to the fact that the action of offering is conditional on the will or preference of the hearer. Execution strategies, such as Can I get you a drink?, on the other hand, underline the role of $\mathrm{S}$ in carrying out A and so reflect the commissive nature of offers. Finally, offers, given their part directive nature, may also be realised using what are typically directive forms (e.g. via an imperative, such as Have a drink) (Schneider 2003: 183; cf. also Leech 2014: 68, 92). Within these overriding strategy types we find a 
wide range of subordinate offer strategies. Table 1 lists those subordinate strategies identified in the present study of ICE-GB. It also includes details of those conventionalised patterns realising each strategy in ICE-GB (cf. Barron 2005 and Barron 2017a for further details of these strategies).

Table 1. Offer strategies and conventionalised patterns in ICE-GB

\begin{tabular}{ll}
\hline Strategy & Conventionalised pattern \\
\hline 1. PREFERENCE & \\
\hline a. Grammatically elliptical & NP? \\
bP for everyone? & Will you have NP? \\
b. Question future act of hearer & What are you having? \\
& Are you having NP? \\
& Do you want NP? \\
c. Question desire & Do you want VP? \\
& You don't want NP. \\
& Need NP? \\
d. Question need & Would you like NP? \\
e. Question wish & If anyone would like NP? \\
& Would anybody like VP? \\
& What would you like? \\
\hline
\end{tabular}

2. EXECUTION

a. Question future act of speaker

Shall I VP?

b. State speaker ability

I can VP

I could VP

c. State speaker desire

I want to VP

d. State speaker obligation

I better VP

e. State speaker willingness

I don't mind if S

\begin{tabular}{ll}
\hline 3. DIRECTIVE & \\
\hline a. Imperative & VP \\
& You VP (e.g. you try NP) \\
b. State permission & You can VP \\
c. Suggestory formulae ${ }^{1}$ & Why don't you VP? \\
& If ..., let's just VP
\end{tabular}

4. OTHER

a. Hint

There is NP (e.g. There's grapefruit juice as well ...)

1 In Barron (2005: 152), suggestory formulae were coded as preference strategies given that the realisations recorded were of the form how about $N P$ ? and thus consult $\mathrm{H}$ on his/her preferences. However, all of the suggestory formulae in the present corpus are of a directive nature, formally taking rather forms closely related to directives, such as suggestions or requests (Why don't you VP?, Let's VP) (cf. also Leech 2014: 138). 
In Brown and Levinson's $(1978,1987)$ terms, the act of offering enhances H's positive face, i.e. their need to be accepted and liked by others, given that $\mathrm{S}$ is offering to do something for $\mathrm{H}$ and given that - in the case of a correct guess $-\mathrm{s} /$ he shows familiarity with H's needs (cf. also Leech 2014: 110). In addition, the act of offering enhances S's positive face as $\mathrm{H}$ is likely to look more favourably on $\mathrm{S}$ (cf. also Leech 2014: 110). However, at the same time, S, in offering, threatens his/ her own negative face by reducing his/her own freedom of action in committing himself/herself to the action A. Also, if S offers a future act which is not welcomed by $\mathrm{H}$, this may threaten H's positive face and indeed the act of second-guessing H's needs may threaten H's negative face. Finally, should the proposed act not be accepted by H, S's positive face may be threatened (although the threat is minimised given that offers are conditional speech acts; cf. Wierzbicka 1987: 96).

Building on Brown and Levinson (1978, 1987), Leech (2014: 11-13) identifies pos-politeness (positive-politeness) strategies which are employed to enhance H's face and neg-politeness (negative-politeness) strategies which mitigate a potential face-threat. ${ }^{2}$ Offers themselves, like invitations or compliments, are an instance of pos-politeness, as they enhance the H's face (cf. above). Since pos-politeness is scalar, the positive value of such acts can be strengthened and made more difficult to refuse. Thus, an offer of cake, might be enhanced with pos-politeness by expressing it using an emphatic imperative such as do have some cake. Also, the use of grounders, i.e. reasons why an offer should be accepted, may be used to strengthen illocutionary force, as seen in the addition of You've had plenty of veggies in the offer Uhm <,> you can break into the pears if you want to or have a piece of choccy. You've had plenty of veggies (ICE$\mathrm{GB}$, s1a-023). Using pos-politeness, "we magnify or strengthen the expression of (positive) value" (Leech 2014: 12, original emphasis). Neg-politeness, on the other hand, "diminish[es] or soften[s] the expression of (negative) value in the transaction" (Leech 2014: 12, original emphasis). It functions to minimise potential offense and is used, for instance, when $S$ is not completely certain if his/her offer is of value to H (cf. Leech 2014: 183). In the latter example, the explicit conditional if you want highlights, for instance, that it is $\mathrm{H}$ who decides on whether the act is carried out or not, paying heed to his/her negative face. This example also shows clearly that pos-politeness and neg-politeness may co-occur.

2 Leech's (2014) pos-politeness and neg-politeness strategies differ from the positive and negative strategies put forward by Brown and Levinson (1987) in a number of ways. Leech's concept does not, for instance, include strategies employed merely to reduce social distance and not to enhance H's face. The use of elliptical forms, such as orange juice? (ICE-GB, s1a-046), is an example (cf. also footnote 9). 
Finally, from a sequential perspective, offers form the first pair part of offeracceptance/refusal adjacency pairs, with refusals the dispreferred second pair part. From a discourse analytical perspective, we differentiate between initiative offers and reoffers. Initiative offers are defined as the first move in an initial or subsequent offer exchange (Schneider 2000: 295) where subsequent offer exchanges involve offers following an initial offer. Initiative offers in such latter exchanges frequently include the word another in hospitable offers (Schneider 2003: 189). Reoffers, on the other hand, are "further attempts on the part of the speaker to reiterate a particular initiative offer within one offer sequence" (Barron 2003: 127). They follow an initial refusal and when realised ritually frequently take the form of are you sure? The present analysis focuses exclusively on initiative offers (cf. section 3).

\subsection{Offers in English}

Relative to speech acts, such as requests, offers reveal a dearth of research. Nonetheless, offers in English have been analysed from various perspectives. Research on English native speaker (NS) offer realisations includes scholarship by Aijmer (1996), Curl (2006), Davidson (1984, 1990), Edmondson and House (1981: 136-137), Leech (2014: 180-186), Schneider (2003: 181-193) and also by Wierzbicka (1985), the latter on Australian English offers. In addition, research has been conducted on offers across the varieties of English within the context of variational pragmatics. In line with the principle of contrastivity in variational pragmatics (cf. Barron and Schneider 2009; Schneider 2010: 252), such analyses involve contrasts across two or more varieties of English, one of these frequently being British English given its status as the standard variety/one of the standard varieties taught around the world (cf. Seargeant 2012). Variational pragmatic analyses on offers include those by Barron (2005, 2011, 2017a). Finally, research on offers within the context of cross-cultural/ intercultural research has frequently compared offers in English with offers in other languages. Such studies include for English/Arabic Alaoui (2011) and Grainger et al. (2015), for English/ Chinese Yongbing (1998), for English/German Barron (2003), for English/Greek Sifianou (1992) and for English/Japanese Fukushima and Iwata (1987).

Research on offers has employed a range of data types, among these roleplay data (Edmondson and House 1981), fictional material (Schneider 2003), naturally-occurring data (Curl 2006; Davidson 1984, 1990; Sifianou 1992), intuitive/observational data (Alaoui 2011; Sifianou 1992; Wierzbicka 1987; Yongbing 1998) and production questionnaire data (Barron 2003, 2005; Fukushima and Iwata 1987). Studies based on corpus data include those by Barron (2011, 2017a), 
using data taken from the British and Irish components of the International Corpus of English (ICE). In addition, Leech's (2014) description of offers is based on data taken from the British National Corpus (BNC) and the Longman Corpus of Spoken American English (LCAE). Aijmer's (1996) description is based on data from the London-Lund Corpus of Spoken English (LLC), and Schneider's (2003) description of diminutive use in offers from the LLC and two further smaller corpora of everyday interactions (cf. Schneider 2003: 73). With its focus on investigating the distribution of offer types, strategies and modification in ICE-GB, the present analysis of offers in ICE-GB adds to the studies in corpus pragmatics and in particular to the corpus studies of offers in British English. We turn now to the methodological details.

\section{Analysing offers in ICE-GB}

The present study of offers in ICE-GB focuses on realisations of initiative offers, that is, of offers which form the first move in an initial or subsequent offer exchange (cf. section 2.1). ${ }^{3}$ This definition thus excludes reoffers, pre-offers (involving, e.g., checks via requests for information that the preparatory conditions for realisation of an offer prevail), and also offers issued by offerees themselves in the context of negotiating an initiative offer. ${ }^{4}$

\subsection{Offer retrieval in corpus-data}

Given the lack of speech act annotation in ICE-GB, a difficulty of many present-day corpora (cf. Rühlemann and Aijmer 2014), the present analysis used an electronic form-based search of formulaic patterns or functional lexical segments. The search strings employed were based on previous research on offers by Barron (2005), and also by Searle (1975), Schiffrin (1994), Aijmer (1996) and Leech (2014: 180-186). They included the performative verb offer, conventionalised realisation patterns of offer strategies drawn from the literature (cf. Table 1 above for examples), frequent modification used in offers (if you want, if you wish),

\footnotetext{
3 It should be noted that the definition of initiative offers includes offers addressed to individuals who have already received a previous general offer.

4 An example of such an offer issued by an offeree in the context of offer negotiation is seen in s1a-045 in ICE-GB. In this transcript, an offer to use a particular book (Would you like me to use your this book or...) is refused with another offer (Let's use my book<,,> because then you don't you can still use yours ...). Such offers are not included in the analysis as these are categorised as refusals in the first instance.
} 
common linguistic features (for you, for everyone, anyone, anybody), reoffer formulae (e.g. are you sure?, I insist), and routine responses to offers, such as thanks or please. Topic-oriented searches (e.g. coffee, tea) were also conducted and editorial comments were searched for comments such as offered tea. In addition, imperative forms were searched for via a POS-tagger. All forms were combined with several wildcards, symbols used to represent any one (or more) character or word, in order to minimise the possibility of not retrieving offers due to the presence of features, such as self-repair, false starts, filled hesitations or other speech related phenomenon (cf. Jucker 2009: 1623). Nonetheless, it is clear that recall errors are still possible as the forms and phrases guiding the research do not necessarily account for the full range of linguistic forms for making offers. In addition, elliptical offers taking the form of noun phrases (e.g. wine?), indirect non-conventionalised offers or non-verbal offers could not be searched for directly, but rather had to rely on topic-oriented searches or searches for routine responses to potentially elicit such forms (cf. Barron 2017a for an extensive discussion of the limitations of form-based functional analysis; cf. also Garcia McAllister 2015: 29).

In production questionnaire analysis, the elicited speech act is easily controlled via the situational description which provides implicit or explicit clues as to the speech act required and also via dialogue initiations and/or a hearer responses, the latter of which signal uptake (cf. Barron 2017b; Grainger and Harris 2007: 2-3). In corpus research on speech act realisations, on the other hand, situational information is frequently missing. This difficulty as well as the general difficulty of a lack of form-function equivalence in speech act realisations and also the overlap between offers and further speech acts, such as undertakings, invitations, promises and requests, makes offer identification difficult. ${ }^{5}$ Given such obstacles, it was necessary to pay a high level of attention to the identification of offers from the concordance lines returned to ensure that the realisations at hand represented realisations of offers. To realise this aim, three broad criteria were developed and used to disambiguate an utterance's illocution and to identify offers, namely the propositional content, the context of use and hearer uptake (cf. Barron 2017a for further details). Of these, uptake was taken as an obligatory criterion (cf. Sidnell 2009). As such, the analysis captures the pragmatic effect of a particular utterance on the dialogue rather than focusing exclusively on a speaker's intention. Any unclear cases were excluded from the analysis.

5 Offers border on suggestions but differ from these in that offers benefit the hearer, but not clearly the speaker. They also border on invitations as both are conditional with a potential cost to $\mathrm{S}$ and a benefit to $\mathrm{H}$. However, invitations generally deal with future participation in or attendance at a particular occasion, such as a party, hosted by the $S$ (e.g. García 1999, 2008). 


\subsection{ICE-GB as a data source}

The data for the present study were drawn from the British component of the International Corpus of English. The data were gathered in the early 1990s and compiled at the Survey of English Usage (SEU), University College London. The speakers of the British component of the ICE were born in England, Scotland or Wales except for a minority of cases where the informants were born elsewhere but moved to Britain early in life (cf. UCL Survey of English Usage). In addition, a limited number of speakers were exposed to continued influence from other cultures via a parent with a different mother tongue (e.g. a speaker with a Spanish father and a mother who was a gipsy). These minority cases were excluded from the present analysis. All speakers are educated speakers of English over the age of 18 , where educated is defined as having at least a high school education.

The present analysis focuses on a sub-section of the overall ICE-GB corpus, namely the genre of private spoken face-to-face conversations. In total, 90 such texts exist. However, a close inspection of the data revealed that the face-to-face conversations of the British component involved a mixture of conversations of an official (e.g. interviews, service interactions) and non-official nature. In the present context, only non-official conversations were analysed. The British subcorpus, thus, amounted to 57 texts (116,179 words) of a potential total 90 texts.

\section{Offers in ICE-GB}

\subsection{Offer types in ICE-GB}

The present analysis revealed four offer types to be present in ICE-GB, the first three of which have previously been identified in offer research. The four types include:

\subsubsection{Hospitable offers}

Hospitable offers have been described by Schneider (2003: 182) as being situation-specific. They are generally realised in "social gatherings such as dinners, receptions, parties" in which the role of host/hostess and guest is predefined and hosts are responsible for looking after their guests. Such offers are issued by hosts and include in the present context offers of food, drink and cigarettes and also offers to use the bathroom. They are also found in the context of the home. An example of an hospitable offer is seen in the offer of gravy in (1). 
(1)
ICE-GB:S1A-012
D: Uhm who hasn't got some gravy
D: $\quad$ Have some gravy Rob $<,>$
A: Cheers $<$, , $>$

\subsubsection{Offers of assistance}

In contrast to hospitable offers, offers of assistance are situation-independent, occurring in a wide range of situations among friends, family, acquaintances, colleagues and strangers. They are defined as offers in which speakers offer to do something for $\mathrm{H}$ which they believe is of benefit to $\mathrm{H}$. This future act may be, as Schneider (2003: 181) states, something which "in the speakers' view, may cause the hearer difficulty or inconvenience" (cf. examples (2) and (3) below, the former an offer to tape someone unable to do it themselves; the latter an offer to cancel a previous appointment due to potential time constraints). Offers of assistance may, however, also be acts of assistance which are costly to $\mathrm{S}$ which $\mathrm{S}$ believes to be potentially beneficial to $\mathrm{H}$ without necessarily causing him/ her difficulty. Example (4), an offer to go sight seeing with A, is a case in point. ${ }^{6}$
ICE-GB:S1A-042 \#127
C: Have you got his album
B: Yeah
C: I'd really love to tape it from you if you if you didn't mind
B: Yeah
B: If you give me a tape I've got a tape to tape and I can run it off
C: Oh great that'd be
C: Well
C: I mean
C: $\quad$ cos a actually thinking about it I've not got a uhm record player or anything
C: $\quad$ So yeah
C: <unclear-word>

6 Despite having much in common with invitations, (3) is not classified as an invitation because it does not deal with potential attendance at a particular occasion hosted by S. (e.g. García 1999, 2008) (cf. also footnote 5).

7 In (2), the offer to tape something is issued in response to a request for help in C carrying out the act of taping (I'd really love to tape it from you if you if you didn't mind) (cf. also Sidnell 2009: 218 on the presence of descriptions of speaker-trouble preceding offers). 

B: You can make tunes from it
C: $\quad$ Oh $\operatorname{good}<$, ,

(3) ICE-GB:S1A-048

C: $\quad$ So Sunday Monday keep free cos that Sunday's dinner with you <,> at your mum's

C: <unclear-word $><$ unclear-word $>$

A: Yeah

A: Listen

A: If you want to put that off honestly I don't mind

C: No I don't no cos you know

A: Yeah what about Rosie

A: I mean you cos you haven't got much time over here

B: $\quad$ No listen I I ..........................

(4) ICE-GB:S1A-045:

B: I was wondering $<,>$

B: would you like to do some sight singing

A: $\mathrm{Mm}$

A: Yes

A: I'd love to

\subsubsection{Gift offers}

Hua, Wei, and Yuan (2000) examine gift offers in the Chinese context. They identify two functions of this offer type, a) to express friendship and b) to coerce a person into indebtedness in the context of bribery (2000: 84). Gift offers in the present corpus occur in informal situations, such as in (5), where B offers A a gift of a Labour poster (one stands for the poster mentioned), and also include gift offers of clothes or of jewellery. No offers were recorded in the context of giftbringing on social occasions, such as birthdays or weddings (cf. Hua, Wei, and Yuan 1998, 2000).

(5) ICE-GB:S1A-069:

B: You can have one <unclear-words>

A: Thank you

Added to the above three offer types previously identified in the literature were offers of verbal goods identified in the present analysis. 


\subsubsection{Offers of verbal goods}

Offers of verbal goods include offers to tell a joke as in (6). Such offers receive a response but the response may potentially be viewed as insincere and ironic ( $\mathrm{Oh}$ God no come on), and the joke simply told regardless (Why does it take ten women with P M T to change a light bulb).

(6) ICE-GB:S1A-041:

B: I said did you hear my joke

B: Do you want to hear my joke

A: Oh God no

A: $\quad$ Come on $<$,>

B: Why does it take ten women with P M T to change a light bulb

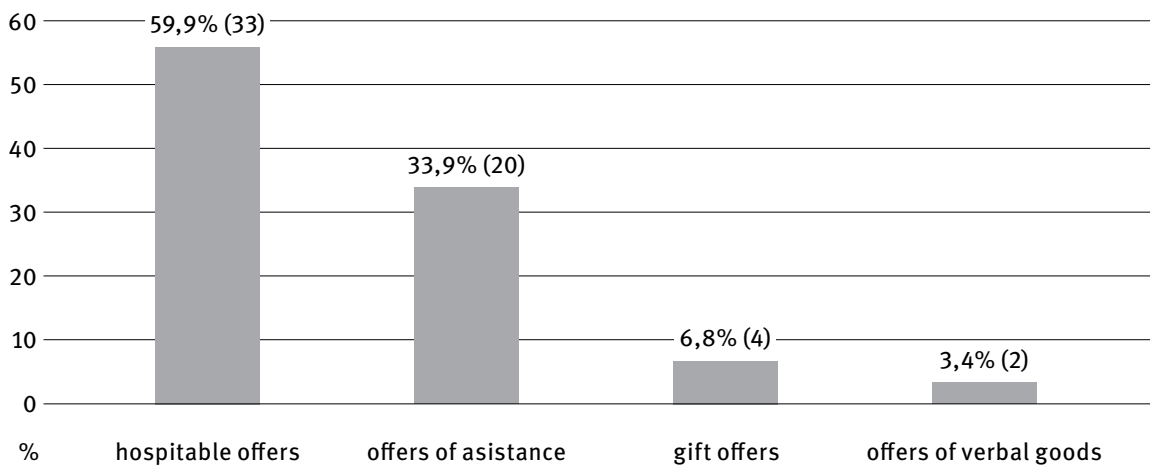

Figure 1. Offer types in ICE-GB $(n=59)$

Frequency-wise, most offers in the corpus were hospitable offers (55.9\%) as seen in Figure 1. These were followed by offers of assistance (33.9\%). Section 4.2 investigates correlations between offer types, strategies and modification. It is this analysis to which we now turn.

\subsection{Offer types, offer strategies and offer modification in ICE-GB}

An in-depth analysis of offer type and offer strategy reveals some interesting correlations. These are shown in Table 2 where we see a clear preference for hospitality offers to be realised using a preference strategy $(p=0.000$, Fisher's exact test), with $78.8 \%$ of all hospitable offers realised using this strategy type. Directive strategies are another option (18.2\%) but execution strategies are not used 
at all in realising this offer type. In contrast, offers of assistance are realised predominantly via an execution strategy, 85\% (17) of this offer type making use of these strategies ( $\mathrm{p}=0.000$, Fisher's exact test). On the level of the subordinate strategies, a state speaker ability strategy is preferred in offers of assistance $(45 \%)(\mathrm{p}=0.000$, Fisher's exact test) as well as a question future act of speaker strategy (25\%) ( $p=0.005$, Fisher's exact test).

Table 2. Offer strategy type and offer strategies across hospitable offers and offers of assistance in ICE-GB

\begin{tabular}{lrr}
\hline & Hospitable offers $(\mathrm{n}=33)$ & Offers of assistance $(\mathrm{n}=20)$ \\
\hline Grammatically elliptical & $15.2 \%(5)$ & - \\
Question future act of hearer & $18.2 \%(6)$ & - \\
Question desire & $21.2 \%(7)$ & $5 \%(1)$ \\
Question need & $3.0 \%(1)$ & - \\
Question wish & $21.2 \%(7)$ & $10 \%(2)$ \\
\hline TOTAL PREFERENCE & $78.8 \%(26)$ & $15 \%(3)$ \\
\hline Question future act of speaker & - & $25 \%(5)$ \\
State speaker ability & - & $45 \%(9)$ \\
State speaker desire & - & $5 \%(1)$ \\
State speaker obligation & - & $5 \%(1)$ \\
State speaker willingness & - & $5 \%(1)$ \\
\hline TOTAL EXECUTION & - & $85 \%(17)$ \\
\hline Imperative & $9.1 \%(3)$ & - \\
State permission & $3.0 \%(1)$ & - \\
Suggestory formulae & $6.1 \%(2)$ & - \\
\hline TOTAL DIRECTIVE & $18.2 \%(6)$ & - \\
\hline Hint & $3.0 \%(1)$ & - \\
\hline TOTAL OTHER & $3.0 \%(1)$ & \\
\hline
\end{tabular}

Turning now to offer modification, the use of modification devices to mitigate or intensify its force. From the point of view of politeness, offers enhance H's positive face (cf. section 2.1). Thus, pos-politeness modification strategies may be used to increase or intensify the force of such offers. On the other hand, given possible threats to S's and H's particular face wants (cf. also section 2.1), negpoliteness strategies may be employed to mitigate force. In addition, combinations of pos-politeness and neg-politeness may occur within one initiative offer (as seen in Table 3 by the fact that the pos-politeness or neg-politeness figures do not equal the sum of pos-politeness and neg-politeness alone). 
Table 3. Pos-politeness and neg-politeness strategies employed across hospitable offers and offers of assistance in ICE-GB

\begin{tabular}{lrr}
\hline & Hospitable offers $(\mathrm{n}=33)$ & Offers of assistance $(\mathrm{n}=20)$ \\
\hline Pos-politeness & $24.2 \%(8)$ & $45 \%(9)$ \\
Neg-politeness & $33.3 \%(11)$ & $65 \%(13)$ \\
Pos-politeness or neg-politeness & $48.5 \%(16)$ & $85 \%(17)$ \\
\hline
\end{tabular}

Table 3 shows the use of pos-politeness and neg-politeness modification strategies with hospitable offers and offers of assistance in the corpus at hand. ${ }^{8}$ Despite the differences on the level of the strategy type highlighted above, both pos-politeness and neg-politeness alone or in combination with each other are used with both of these main offer types. Offers of assistance do, however, show a higher use of negative politeness (65\% [13] vs. 33.3\% [11] for hospitable offers [Fisher's exact test, $\mathrm{p}=0.045$ ]). In addition, the overall investment in politeness is greater in these offers of assistance, with the vast majority of offers $(85 \%$ compared to $48.5 \%$ for hospitable offers) using either pos-politeness or neg-politeness in offer realisations (Fisher's exact test, $\mathrm{p}=0.009$ ).

Table 4 summarises the individual types of pos-politeness and neg-politeness employed in these offers with examples. Neg-politeness types include conditional clauses (also termed explicit conditionals) (Aijmer 1996: 191; Barron 2005: 161; Brown and Levinson 1987: 72), conditionals (cf. Leech 2014: 183 on the hypothetical past tense serving to distance the offer from reality and thus represent a tentative formulation), impersonal constructions, lexical downtoners, subjectivisers (Leech 2014: 183), consultative devices, hesitation/restarters and clarifications of the optionality of offers. Pos-politeness types, designed to underline or increase the positive force of offers, include grounders (Aijmer 1996: 191; Barron 2005: 164-165; Brown and Levinson 1987: 128), repetition of the offer, lexical upgrading, negation (Leech 2014: 182), understaters/ diminutives (Eshreteh 2016: 142; Leech 2014: 185-186), downplaying the offer (both of the latter which downplay the cost of A to S) and the use of tags.

Table 4 also shows the level of use of each pos-politeness and neg-politeness element across offer type. Figures in this table are given as a percentage of the total number of each offer type. However, since combinations of modifiers also occurred, the overall total exceeds $100 \%$. The use of pos-politeness strategies across offer type is broadly similar across offer type without any statistically significant differences with the exception of a slightly significantly higher use

8 We focus here on modifiers while at the same time recognising that the choice of a particular strategy may also orient towards pos-politeness (e.g. use of an imperative) or neg-politeness (e.g. question ability strategy). 
of repetition in offers of assistance (Fisher's exact test, $p=0.049$ ). Within the negpoliteness strategies, conditional clauses, which explicitly underline the conditional nature of offers, are employed to a higher extent in offers of assistance relative to hospitable offers (hospitable: $9.1 \%$ vs. assistance: 35\%, Fisher' exact test, $\mathrm{p}=0.030$ ). The higher use of such conditionals also relates to strategy preferences - in this case the high use of an execution strategy in offers of assistance - given that preference strategies already include explicit reference to the conditional nature of offers, as in Do you want NP? and thus do not frequently include such modification (cf. Barron 2005: 161). Indeed, the only preference strategy with a conditional clause in the database was the offer If anyone would like NP?

Table 4. Pos-politeness and neg-politeness types employed across hospitable and offers of assistance in ICE-GB ${ }^{9}$

\begin{tabular}{|c|c|c|c|}
\hline & Example & $\begin{array}{r}\text { Hospitable } \\
\text { offers }(n=33)\end{array}$ & $\begin{array}{r}\text { Offers of assis- } \\
\operatorname{tance}(n=20)\end{array}$ \\
\hline \multicolumn{4}{|l|}{ NEG-POLITENESS } \\
\hline $\begin{array}{l}\text { Conditional } \\
\text { clauses }\end{array}$ & $\begin{array}{l}\text { I can I can dig the stuff out on it if if if } \\
\text { there's any interest (ICE-GB, s1a-012) }\end{array}$ & $9.1 \%(3)$ & $35 \%(7)$ \\
\hline Conditional & $\begin{array}{l}\text { I tell you what I could look out for and } \\
\text { that's ... (ICE-GB, s1a-007) }\end{array}$ & $21.2 \%(7)$ & $25 \%(5)$ \\
\hline $\begin{array}{l}\text { Impersonal } \\
\text { constructions }\end{array}$ & $\begin{array}{l}\text { if anyone would like some ice cream } \\
\text { (ICE-GB, s1a-073) }\end{array}$ & $6.1 \%(2)$ & - \\
\hline Lexical downtoner & $\begin{array}{l}\text { well I can only have a look } \\
\text { (ICE-GB, s1a-046) }\end{array}$ & - & $5 \%(1)$ \\
\hline Subjectiviser & $\begin{array}{l}\text { so why don't you have my one cos I think } \\
\text { I might nip off shortly (ICE-GB, s1a-042) }\end{array}$ & $3.0 \%(1)$ & - \\
\hline $\begin{array}{l}\text { Consultative } \\
\text { device }\end{array}$ & $\begin{array}{l}\text { Do you think you would like to eat? } \\
\text { (ICE-GB, s1a-046) }\end{array}$ & $3.0 \%(1)$ & - \\
\hline Hesitation/Re-starts & $\begin{array}{l}\text { I could uhm get you that other book } \\
\text { (ICE-GB, S1a-053) }\end{array}$ & $9.1 \%(3)$ & $10 \%(2)$ \\
\hline $\begin{array}{l}\text { Clarify optionality } \\
\text { of offer }\end{array}$ & $\begin{array}{l}\text { I mean you don't have to } \\
\text { (ICE-GB, s1a-046) }\end{array}$ & $3.0 \%(1)$ & - \\
\hline
\end{tabular}

9 As mentioned above in section 2.1 (cf. also footnote 2), Leech (2014: 99) does not include claims of common ground or solidarity in his concept of positive politeness arguing that they are employed to underline camaraderie and friendship rather than to enhance face. While it is recognised that these concepts are intricately related, the present overview does not take alerters (external elements to the offer, such as first names, which function to draw the interlocutor's attention to the offer (Blum-Kulka et al. 1989)), the use of ellipsis or the use of linguistic items designed to underline common context into account. Indeed, the use of alerters may simply function as a deictical element in large groups. For instance, there are a number of occasions of offers in my data where an offer did not receive uptake (and was thus not included in the present corpus) but was rephrased in the same way with the inclusion of an alerter and then followed by uptake (and so included in the present corpus). 
Table 4. (continued)

\begin{tabular}{|c|c|c|c|}
\hline & Example & $\begin{array}{r}\text { Hospitable } \\
\text { offers }(n=33)\end{array}$ & $\begin{array}{l}\text { Offers of assis- } \\
\text { tance }(n=20)\end{array}$ \\
\hline \multicolumn{4}{|l|}{ POS-POLITENESS } \\
\hline Grounder & $\begin{array}{l}\text { there's certain things that you can get } \\
\text { cheaper out there so I mean obviously } \\
\text { if there's anything that you want me to } \\
\text { try and get you I can get it cheaper... } \\
\text { (ICE-GB, s1a-048) }\end{array}$ & $6.1 \%(2)$ & $20 \%(4)$ \\
\hline Repetition & $\begin{array}{l}\text { well what books shall I bring along } \\
\text { shall I bring along some books } \\
\text { (ICE-GB, s1a-043) }\end{array}$ & - & $15 \%(3)$ \\
\hline Lexical - upgrading & $\begin{array}{l}\text {... if you want to put that off honestly } \\
\text { I don't mind (ICE-GB, s1a-048) }\end{array}$ & $6.1 \%(2)$ & $25 \%(5)$ \\
\hline Negation & $\begin{array}{l}\text { You don't want any tea } \\
\text { (ICE-GB, s1a-047) }\end{array}$ & $9.1 \%(3)$ & - \\
\hline $\begin{array}{l}\text { Understater/ } \\
\text { diminutive }{ }^{10}\end{array}$ & $\begin{array}{l}\text { so if you feel like uh uhm trying a bit of } \\
\text { walnut pastry kind of cake and putting } \\
\text { things on it judiciously I mean let's just } \\
\text { (ICE-GB, s1a-056) }\end{array}$ & $3.0 \%(1)$ & - \\
\hline Downplay that offered & $\begin{array}{l}\text { Wouldn't be very large but it'd be big } \\
\text { enough to ... (ICE-GB, s1a-007) }\end{array}$ & - & $5 \%(1)$ \\
\hline Tag & $\begin{array}{l}\text { have some nuts why don't you } \\
\text { (ICE-GB, s1a-057) }\end{array}$ & $3.0 \%(1)$ & $5 \%(1)$ \\
\hline
\end{tabular}

\section{Conclusion}

The analysis reveals ICE-GB to include a range of offer strategies and offer types. The most frequent offer types were hospitable offers followed by offers of assistance. These offer types were found to correlate with different strategy types, and modification types. Most typically, hospitable offers in ICE-GB were realised using a conventionalised preference strategy accompanied on occasion by some modification. These findings support those by Barron (2005) in which preference strategies were also revealed to be prototypical across EngE and IrE in the hospitable offer situation included in the production questionnaire analysis. The prototypical use of hearer-oriented preference strategies with hospitable offers - rather than the more indirect speaker-oriented execution strategies - is suggested to relate to the specific context of hospitable offers in which hosts have the obligation to look after their guests and in which guests are entitled - and in

10 This category may include diminutives, such as little or indeed quantifiers, such as drop (drop of tea) which function as inherent diminutives (cf. Schneider 2003: 190). 
some instances - obliged to accept such attention. In other words, in such situations $\mathrm{S}$ has a high right to offer. A hearer-oriented strategy is, thus, acceptable.

Offers of assistance in the corpus, in contrast, were realised predominantly using an execution strategy. Similarly, in Barron (2005), execution strategies, particularly the state ability strategy, were prototypical in many non-hospitable situations. Such strategies underline the role of the speaker rather than the hearer and are thus less direct relative to preference strategies. Their use reflects a higher level of negative face-threat in such situations where role relations are less standard. Neg-politeness modification and indeed overall modification is higher in offers of assistance than in the case of hospitable offers, with the vast majority of offers of assistance exhibiting some modification in the form of pospoliteness and/ or neg-politeness. Within the neg-politeness strategies, conditional clauses were used to a comparatively large extent.

Further research prospects are many. Given low occurrences of the remaining offer types identified, namely gift offers and offers of verbal goods, strategy/ modification correlations could not be carried out. This is an area ripe for future research. Further research desiderata include an analysis of the present data by gender given particularly a female bias (64.4\% female; $35.6 \%$ male) in the offers identified in the present corpus. Finally, given the present form-focused analysis and the related difficulties of recall mentioned in section 3.1, a line-by-line reading of the transcripts of the corpus focused on identifying offers in context, would also be welcomed. In the British context, audio-recordings are available, which support such an analysis (cf. Garcia McAllister 2015: 32). We look forward to future analyses.

\section{Transcription conventions}

$\begin{array}{ll}<,> & \text { short pause } \\ <, \text {, } & \text { long pause } \\ <\text { unclear }>\ldots<\text { /unclear }> & \text { unclear speech }\end{array}$

\section{References}

Aijmer, Karin. 1996. Conversational routines in English: Convention and creativity. London: Longman.

Alaoui, Sakina M. 2011. Politeness Principle: A comparative study of English and Moroccan Arabic requests, offers and thanks. European Journal of Social Sciences 20(1). 7-15.

Barron, Anne. 2003. Acquisition in interlanguage pragmatics. Amsterdam \& Philadelphia: John Benjamins

Barron, Anne. 2005. Offering in Ireland and England. In Anne Barron \& Klaus P. Schneider (eds.), The pragmatics of Irish English, 141-176. Berlin \& New York: Mouton de Gruyter. 
Barron, Anne. 2011. Variation revisited: A corpus analysis of offers in Irish English and British English. In Joachim Frenk \& Lena Steveker (eds.), Anglistentag 2010 Saarbrücken: proceedings, 407-419. Trier: Wissenschaftlicher Verlag Trier.

Barron, Anne. 2017a. The speech act of "offers" in Irish English. World Englishes 36(2).

Barron, Anne. 2017b. Variational pragmatics. In Anne Barron, Gerard Steen \& Gu Yueguo (eds.), Routledge handbook of pragmatics, 91-104. London \& New York: Routledge.

Barron, Anne \& Klaus P. Schneider. (eds.). 2009. Variational Pragmatics. [Special issue]. Intercultural Pragmatics 4(6).

Blum-Kulka, Shoshana, Juliane House \& Gabriele Kasper. 1989. The CCSARP coding manual. In Shoshana Blum-Kulka, Juliane House \& Gabriele Kasper (eds.), Crosscultural pragmatics: Requests and apologies, 273-294. Norwood, NJ: Ablex.

Brown, Penelope \& Stephen C. Levinson. 1978. Universals in language usage: Politeness phenomena. In Esther N. Goody (ed.), Questions and politeness: Strategies in social interaction, 56-289. Cambridge: Cambridge University Press.

Brown, Penelope \& Stephen C. Levinson. 1987. Politeness: Some universals in language use. Cambridge: Cambridge University Press.

Curl, Traci S. 2006. Offers of assistance: Constraints on syntactic design. Journal of Pragmatics 38. 1257-1280.

Davidson, Judy Arlene. 1984. Subsequent versions of invitations, offers, requests, and proposals dealing with potential or actual rejections. In John Maxwell Atkinson \& John Heritage (eds.), Structures of social action: Studies in conversational analysis, 102-128. Cambridge: Cambridge University Press.

Davidson, Judy Arlene. 1990. Modifications of invitations, offers and rejections. In George Psathas (ed.), Interaction competence (Studies in Ethnomethodology and Conversation Analysis 1), 149-179. Washington, DC: International Institute for Ethnomethodology and Conversation Analysis, etc.

Edmondson, Willis \& Juliane House. 1981. Let's talk, and talk about it: A pedagogic interactional grammar of English. München: Urban und Schwarzenberg.

Eshreteh, Mahmood K. M. 2016. A pragmatic analysis of diminutives in Palestinian society. International Journal of Language Studies 10(4). 131-148.

Fukushima, Saeko \& Yuko Iwata. 1987. Politeness strategies in requesting and offering. Japanese Association of College English Teachers Bulletin (JACET Bulletin) 18. 31-48.

Garcia McAllister, Paula. 2015. Speech acts: A synchronic perspective. In Karin Aijmer \& Christoph Rühlemann (eds.), Corpus pragmatics. A handbook, 29-51. Cambridge: Cambridge University Press.

García, Carmen. 1999. The three stages of Venezuelan invitations and responses. Multilingua 18(4). 391-433.

García, Carmen. 2008. In Klaus P. Schneider \& Anne Barron (eds.), Variational pragmatics: $A$ focus on regional varieties in pluricentric languages, 269-305. Amsterdam \& Philadelphia: John Benjamins.

Grainger, Karen \& Sandra Harris. 2007. Apologies: Introduction. [Special issue]. Journal of Politeness Research 3(1). 1-9.

Grainger, Karen, Zainab Kerkam, Fathia Mansor \& Sara Hills. 2015. Offering and hospitality in Arabic and English. Journal of Politeness Research 11(1). 41-70.

Hancher, Michael. 1979. The classification of cooperative illocutionary acts. Language in Society 8. 1-14.

Hua, Zhu, Li Wei \& Qian Yuan. 1998. Gift offer and acceptance in Chinese culture: Contexts and functions. Journal of Asian Pacific Communication 8(2). 87-101. 
Hua, Zhu, Li Wei \& Qian Yuan. 2000. The sequential organisation of gift offering and acceptance in Chinese. Journal of Pragmatics 32(1). 81-103.

International corpus of English. http://ice-corpora.net/ice/ (accessed 19 August 2016).

Jucker, Andreas H. 2009. Speech act research between armchair, field and laboratory: The case of compliments. Journal of Pragmatics 41.1611-1635.

Leech, Geoffrey. 2014. The pragmatics of politeness. Oxford: Oxford University Press.

Pérez Hernández, Lorena. 2001. The directive-commissive continuum. Miscelánea: A Journal of English and American Studies 23.77-98.

Rühlemann, Christoph \& Karin Aijmer. 2014. Corpus pragmatics: Laying the foundations. In Karin Aijmer \& Christoph Rühlemann (eds.), Corpus pragmatics. A handbook, 1-26. Cambridge: Cambridge University Press.

Schiffrin, Deborah. 1994. Approaches to discourse. Malden, MA: Blackwell.

Schneider, Klaus P. 2000. Diminutives in discourse: Sequential aspects of diminutive use in spoken interaction. In Malcolm Coulthard, Janet Cotterill \& Francis Rock (eds.), Dialogue analysis VII: Working with dialogue (Selected papers from the 7th International Association of Dialogue Analysis Conference Birmingham 1999), 293-300. Tübingen: Niemeyer.

Schneider, Klaus P. 2003. Diminutives in English. Tübingen: Niemeyer.

Schneider, Klaus P. 2010. Variational pragmatics. In Mirjam Fried, Jan-Ola Östman \& Jef Verschueren (eds.), Variation and change: Pragmatic perspectives (Handbook of Pragmatics Highlights 6), 239-267. Amsterdam \& Philadelphia: John Benjamins.

Seargeant, Philip. 2012. Exploring World Englishes. Language in a global context. Oxon \& New York: Routledge.

Searle, John R. 1975. Indirect speech acts. In Peter Cole \& Jerry. L. Morgan (eds.), Speech acts (Syntax and Semantics 3), 59-82. New York: Academic Press.

Searle, John R. 1976. A classification of illocutionary acts. Language in Society 5. 1-23.

Sidnell, Jack. 2009. Sequences. In Sigurd D’hondt, Jan-Ola Östman \& Jef Verschueren (eds.), The pragmatics of interaction, 215-239. Amsterdam \& Philadelphia: John Benjamins.

Sifianou, Maria. 1992. Cross-cultural communication: Compliments and offers. Parousia 8. 49-69.

UCL Survey of English Usage. http://www.ucl.ac.uk/english-usage/projects/ice-gb/design. htm (accessed 10 August 2016).

Wierzbicka, Anna. 1985. Different cultures, different languages, different speech acts: Polish vs. English. Journal of Pragmatics 9(2-3). 145-178.

Wierzbicka, Anna. 1987. English speech act verbs. A semantic dictionary. Marrickville, Australia: Academic Press.

Wunderlich, Dieter. 1977. Assertions, conditional speech acts, and practical inferences. Journal of Pragmatics 1.13-46.

Yongbing, Liu. 1998. A study of conversational formulas - from a cross cultural perspective. The Internet Journal of Language, Culture and Society 3. http://www.aaref.com.au/en/ publications/journal/archived-articles/issue-03-1998/ (accessed 10 August 2016). 